\title{
Exchange Rate Exposure: Do Asymmetries and Volatilities Matter? Evidence from the Taiwan Stock Market
}

\author{
R. F. Franck Varga ${ }^{1}$ \\ ${ }^{1}$ Department of Global Political Economy, Tamkang University, Taiwan \\ Correspondence: R. F. Franck Varga, Department of Global Political Economy, Tamkang University, Lanyang \\ Campus, 180 Linwei Road, Jiaoshi, I-Lan County, Taiwan. E-mail: 134378@mail.tku.edu.tw
}

Received: April 26, 2013

Accepted: May 14, 2013

Online Published: June 20, 2013

doi:10.5539/ibr.v6n7p120

URL: http://dx.doi.org/10.5539/ibr.v6n7p120

\begin{abstract}
This study investigates foreign exchange exposure and the impacts of asymmetries and volatilities on the daily returns of Taiwanese non-financial firms from 1990 to 2010. 88.8\% of our samples are negatively exposed, companies benefiting from an appreciation of the domestic currency. $14 \%$ of the firms have an asymmetrical profile. If this percentage is not negligible, Taiwanese firms exhibit mainly a symmetric exposure. Currency volatilities have a significant impact for only $7.5 \%$ of the firms, but for $37.38 \%$ of the sample, we observe the existence of an asymmetric volatility. Among them, $65 \%$ exhibit a negative sign meaning that good news have a greater impact on the volatility than bad news, which seems counter-intuitive. These results may be explained by a chasing good news behavior and the effects of a high level of information uncertainty.
\end{abstract}

Keywords: exchange rate exposure, asymmetric exposure, currency volatility, volatility asymmetry

\section{Introduction}

Since the collapse of the Bretton Woods system, changes in exchange rates have been a large subject of interest and concern, knowing that currency volatilities and their associated risks increased dramatically. Financial theory strongly supports that firm value is sensitive to exchange rates movements.

Nevertheless, most of the empirical studies show a small economical and statistical impact of currency risk on stock returns (Note 1). Bartram and Bodnar (2007) consider it as the result from "exposure reducing actions". Bartram, Brown and Minton (2010) confirm that financial hedging limit exposure by at least forty percents. So, the question remains whether exchange rate exposure matters in financial markets by being meaningful for investors.

Some authors argue that sampling and methodologies may also explain the poor empirical evidences. Cash flows are a nonlinear function of exchange rates, so ignoring the nonlinear part of the exposure may lead to wrong conclusions. See for example Koutmos and Martin (2003). Some studies obtain better results when using a sample from a small and open economy. Moran (2005) found that more than $20 \%$ of his Chilean sample is exposed, with nonlinear characteristics.

In this study, we address the key issues mentioned above. Firstly, we are motivated to look for evidence in Taiwan, which is considered to be an open economy (Note 2). Moreover, currency volatility started to increase since Taiwan started a financial liberalization program in 1987. Secondly, we investigate the existence of asymmetric exposure generated by the sign and amplitude of the exchange rate changes. Thirdly, because the potential cash flow consequences, we examine how currency volatility affects the stock returns of Taiwanese firms. Finally, we analyze the volatility of stock returns underlying exchange rate exposure. For example, Kanas (2000) considers that this volatility should be a component of the firm exposure.

The next section presents related papers, followed by the description of the methodology and sample selection in sections 3 and 4. Section 5 reports the main empirical findings and section 6 concludes the paper.

\section{Related Papers}

A large literature followed the seminal paper of Adler and Dumas (1984) who define exchange rate exposure as the impact of unexpected changes in currencies on firm value. Jorion (1990) investigated this phenomenon for a sample of 287 U.S. multinationals firms, using an augmented market model (Note 3): 


$$
R_{i, t}=\beta_{O, i}+\beta_{1, i} R m_{t}+\beta_{2, i} F X_{t}+\varepsilon_{i, t}
$$

where $R_{i, t}$ denotes the stock return, $R m_{t}$ the return on the market index and $F X_{t}$ the change in the exchange rate. But the author found a significant exposure only for 5.23\% of his sample. Likewise, Amihud (1994) does not succeed too even after using for his sample, 32 companies listed in the Fortune magazine's "50 Leading Exporters" list. Bodnar and Gentry (1993), in a multi-country study, find that $21 \%$ to $25 \%$ of the firms in USA, Japan and Canada display an exposure to exchange rate changes, percentage significantly higher than the ones obtained by Choi and Prasad (1995) who used an American dollar index for their US multinational firms: 14.9\% at the firm level and $10 \%$ at the industry level.

Considering the special situation of American companies and currency, authors start to extend their studies outside the USA but with very mixed results. For example, $\mathrm{He}$ and $\mathrm{Ng}$ (1998) find that $26.3 \%$ of their Japanese sample is exposed to an exchange rate index while Bartram (2004) finds that only $7.5 \%$ of his German samples are exposed. Nydahl (1999) documents a higher level of exposure for his Swedish sample (17\%). Dominguez and Tesar (2001) analyze exposure in different, open, mature and developing countries at the firm and industry level. According to the country, they find that between $14 \%$ and $26 \%$ of the firms are exposed.

Among authors who do not document exposure at all, Priestley and Odegaard (2005) investigate without success seven industries in Norway, none being exposed to the USD or ECU.

Several authors choose to study firms' exposure across many countries; for example Bartram and Karolyi (2006) study the impact of the Euro introduction in the EU, and Doidge et al. (2006) who use a large sample of firms from North America, Europe and Asia. Both studies find results in conformity with Griffin and Stulz (2001): the exposure to exchange rate movements is small, both statistically and economically.

Then authors start to consider a change in the methodology usually employed when investigating exposure.

Many studies use an exchange rate index rather than a bilateral exchange rate, which can explain some mixed results. An index is not representative for an individual firm and can imply a diversification effect across currencies. But Bartram (2004) finds that using a bilateral exchange rate does not significantly improve the measure of exposure.

Another change in the methodology is the use of orthogonalized models (Note 4). Again, the results were not very different as for example Choi and Prasad (1995) and Choi et al. (1998). Nevertheless some authors using the orthogonalized model succeeded in obtaining better results, as did Glaum et al. (1998) - 49\% of the sample being exposed, Priestley and Odegaard (2002) - 69\% exposed to the JPY and $40 \%$ to the ECU, Kiymas (2003) $62 \%$ or Chen et al. (2004) $-24 \%$.

Exposure may be a complex concept to measure, especially if we take into account the time the firm needs to adjust its financial management to exchange rate fluctuations or the fact that company information is only disclosed at regular moments in the year hence the time also needed by the market to adjust its valuation process. These facts may lead to mispricing of currencies movements, and push some authors to introduce one more change in the methodology: the lag effect. Therefore, beside contemporaneous exchange rate fluctuations, authors use lagged exchange rate too. Bartov and Bodnar (1994) find some evidence at the one-month lag level, but with a very low adjusted $\mathrm{R}^{2}(0.2 \%)$. Frazer and Pantzalis (2004) obtain some mixed results, with only $9 \%$ of their American sample being exposed. Di Iorio and Faff (2000) find non-significant lag effects.

Another change in methodology has also been proposed to improve the measurement of firms' exposure: time varying factors, by using sub-periods analysis. The problem is that it is not always easy to explain the time variation of the exposure which may have different economic sources or could even been caused by some estimation errors. There are studies providing evidence that exposure is generally more time dependant. Brunner et al. (2000) find that exposure coefficients are not stable over time for their German sample. Muller and Verschoor (2007) find considerable evidence of long-term exposure, the short-term seeming to be well hedged. Chow et al. (1997a, 1997b) assert that market participants may wrongly assess the exchange rate risk in the long run. Koutmos and Martin (2007) find that the variability in the time-varying exposure is smaller (larger) for the largest (smallest) firms and for industrial (technology) firms. The size effect is also confirmed by Hunter (2005).

But ignoring the nonlinear (asymmetric) exposure may also explain why empirical results are mixed. Some authors study asymmetric response to changes in exchange rate, as Bartram (2004), Carter et al. (2005) and Tai (2005). Anyway, they only succeed to display a low marginal improvement.

According some authors such as Muller and Verschoor (2006), the asymmetric link between firms' values and currency changes may have several explanations such as asymmetric hedging (e.g. Allayannis \& Ofek, 2001; 
Miller \& Reuer, 1998; Rossi, 2008; Andren, 2001), incorrect pricing of assets (see for example Muller \& Verschoor, 2006), hysteresis (see Baldwin, 1988; Dixit,1989; for their description of hysteresis models), pricing policies and market structures (e.g. Marston, 1990; Froot \& Klemperer, 1989; Knetter,1994).

Volatility (creating asymmetries and nonlinearities) may also be the key variable (or component) to explain foreign exchange exposure. Authors as Giurda and Tzavalia (2004) and Kanas (2000) show evidence for the existence of asymmetric volatilities. Leverage effect may explain this phenomenon, good (bad) news impacting the ratio debt / equity. But appreciations and depreciations are not automatically good or bad news (Note 5). Maghrebi et al. (2006) state "whether depreciation of domestic currency should be viewed as good news or bad news is an open question" (Note 6).

But beside currency changes, exchange rate volatility should also be a component of firm's exposure through its impact on cash flow. Exchange rate volatility should affect cash flows by modifying the volume of international trade. Several studies as for example Sercu and Vanhule (1992) or Kroner and Lastrapes (1993) among others provide evidence on a relationship between the volume of trade flows and foreign exchange rate volatility (even though the sign of this relationship is subject to disagreement). Hence, the value of the firms should be impacted too. Moreover, currency volatility affects hedging activities and their related financial costs, thus, cash flows should also be affected. Brown (2001) indicates that cash flows of the firms which are actively involved in hedging should be negatively affected when the currency volatility increases.

\section{Methodology}

\subsection{Orthogonalized Model}

In the augmented CAPM model (see Eq. 1), $\beta_{2, i}$ may under/overestimate the firm's true exposure, since currency movements and market returns are correlated (Note 7). To address this issue, we follow Entorf and Jamin (2003) and use an auxiliary regression, described as:

$$
R_{m, t}=\delta_{0}+\delta_{1} F X_{t}+\delta_{m, t}
$$

with $\delta_{m, t}$, the orthogonalized market returns, representing the component of market returns uncorrelated with currency changes. Then rearranging Eq. (1) and Eq. (2), we obtain the orthogonalized model:

$$
R_{i, t}=\beta_{0, i}^{*}+\beta_{1, i} \delta_{m, t}+\beta_{2, i}^{*} F X_{t}+\varepsilon_{i, t}
$$

where:

$$
\begin{aligned}
& \beta_{0, i}^{*}=\beta_{0, i}+\beta_{1, i} \delta_{0} \\
& \beta_{2, i}^{*}=\beta_{2, i}+\beta_{1, i} \delta_{1}
\end{aligned}
$$

$\beta_{o, i} \beta_{1, i}$ and $\beta_{2, i}$ are from the unorthogonalized model $R_{i, t}=\beta_{O, i}+\beta_{1, i} R m_{t}+\beta_{2, i} F X_{t}+\varepsilon_{i, t}$ (Eq. 1). Under (3), $\beta_{2, i}^{*}$ is supposed to show the total impact of exchange rate fluctuations on the firm value. It contains the direct effect $\beta_{2, i}$ as well as the indirect effect $\beta_{1, i} \delta_{1}$.

The indirect effect is also a firm-specific component of the exposure (as the direct effect) in the sense that $\beta_{1, i}$ varies across firms: each company may have a specific relationship with the market portfolio.

\subsection{Multiple Asymmetries and Volatilities}

As mentioned in section 2, asymmetric currency exposure is mainly motivated by the literature investigating asymmetric hedging, hysteresis and pricing-to-market. We will follow related asymmetric models (e.g. Koutmos \& Martin, 2003) by adding to the orthogonalized augmented model (eq. 3) a control variable measuring the impacts of a change in the currency (sign asymmetry).

But as argued by different authors such as Miller and Reuer (1998), firms will start to react only if the change in the currency exceeds a certain threshold (see section 2). We add another control variable to our model to take into account this fact (magnitude asymmetry).

In the previous section, we cited arguments that cash flows (thus the value of the firm) are affected by the exchange rate volatility through the volume of trade and hedging (transaction) cost. So we incorporate a time-varying currency variable into our model in view to investigate how currency volatility may impact the Taiwanese stock returns.

The final adjustment in our model concerns a second kind of volatility: the volatility of stock returns underlying exchange rate exposure. For instance, Kanas (2000) and Giurda and Tzavalia (2004) argued that a part of the 
volatility asymmetry in stocks returns is related to currency changes.

Therefore, our final model is as follows:

$$
\begin{aligned}
R_{i, t} & =\beta_{0, i}^{*}+\beta_{1, i} \delta_{m, t} \\
& +\left(\beta_{2, i}^{*}+\beta_{3, i} D_{\text {sign }, t}+\beta_{4, i} D_{a m p, t}\right) s_{t} \\
& +\beta_{5, i} h_{s, i, t}+\varepsilon_{i, t}
\end{aligned}
$$

where

$s_{t}=$ the unexpected change in the exchange rate

$D_{\text {sign,t }}=1$ if $s_{t}<0$ and 0 otherwise (sign asymmetry)

$D_{\text {amp }, t}=1$ if $\left|s_{t}\right|>\mathrm{x}$ and 0 otherwise; $\mathrm{x}=0.5 \%$ (threshold firms are

supposed to react to - magnitude asymmetry)

$h_{s, i, t}=$ the time-varying exchange rate volatility

$\varepsilon_{i, t}=$ error term which follows a GJR GARCH $(1,1)$ process as:

$\varepsilon_{i, t}=\mu_{i, t} \sqrt{h_{\varepsilon, i, t}}$, and

$h_{\varepsilon, i, t}=\omega \varepsilon+\alpha_{\varepsilon, i} \varepsilon_{t-1}^{2}+\gamma_{i} D_{t-1} \varepsilon_{t-1}^{2}+\beta_{\varepsilon, i} h_{\varepsilon, i, t-1} \quad$ (conditional variance of $\varepsilon_{i, t}$ )

where $D_{t-1}$ is equal to 1 if $\varepsilon_{i, t}$ is negative and 0 otherwise.

Existence of foreign exchange exposure is confirmed if $\beta_{2, i}^{*}, \beta_{3, i}$ (sign asymmetry) and/or $\beta_{4, i}$ (magnitude asymmetry) are statistically significant. So according their signs, asymmetries may increase or decrease the currency exposure. The difficulty in measuring magnitude asymmetries is to find an effective threshold which may depend on several factors such as the size of the firm or the industry to which the company belongs. The way to choose it is quite arbitrary. The rule of thumb is to use as a starting point, the average exchange rate changes during the sample period. More details about the threshold are given in the next section.

In the literature, when $\varepsilon_{i, t}$ (the error term which follows a GJR GARCH $(1,1)$ process - see eq. 6) is positive, it implies that the market has a positive unexpected shock in period $t-1$, defined as good news. Conversely, if $\varepsilon_{i, t}$ is negative, it means that the market has a negative unexpected shock in the previous period, defined as a bad news. In the latter case, the model produces a higher estimate of conditional volatility $\left(\alpha_{i}+\gamma_{i}\right)$, compared to the former case $\left(\alpha_{i}\right)$, assuming that $\gamma_{i}$ is positive.

$\gamma_{i}$ (see conditional variance for equation 6 ) if significant, implies asymmetric volatility of stock returns caused by currency exposure.

The last step to complete our system is to define the exchange rate dynamics. Many previous studies as for example Meese and Singleton (1982), find that exchange rates follow martingale processes, so the best forecast for time $\mathrm{t}+1$ is the value at time $\mathrm{t}$. Therefore, changes in $F X_{t}$ follow a martingale of the form:

$$
F X_{t}=\theta+F X_{t-1}+s_{t}
$$

where $s_{t}$ is the unexpected change (Note 8) in the exchange rate (innovation) used in equation (6). The conditional variance of $s_{t}$ follows a GARCH $(1,1)$ process defined as:

$s_{t}=\rho_{i, t} \sqrt{h_{s, i, t}}$, and

$h_{s, i, t}=\omega s, i+\alpha_{s, i} s_{t-1}^{2}+\beta_{s, i} h_{s, i, t-1} \quad$ (conditional variance of $s_{t}$ )

The time-varying exchange rate volatility $h_{s, i, t}$ is used as a predetermined variable in equation (6).

The system is estimated using a two-step procedure: first, $s_{t}$ and $h_{s, i, t}$ are estimated via maximum likelihood and then their values are used as predetermined variables in the estimation of equation (6).

Exchange rate volatility is measured by $\beta_{5, i}$. For non-financial firms this coefficient is supposed to be negative, companies being not supposed to benefit from larger currency volatility. 


\section{Sample Selection}

We obtained our data from TEJ, a database maintained in Taiwan. Our sample is made of 107 non-financial Taiwanese firms from 1990 to 2010 (Note 9), and listed on the Taiwan Stock Exchange (TSE). We use daily adjusted stock prices. We follow Dominguez and Tesar (2001) by choosing the firm level to avoid the aggregated effect from the industry level.

Moreover, asymmetric behavior can best be captured at the company level. We use the TAIEX, the leading index in the TSE, as a proxy for the market's return.

To avoid currency aggregated effects issues, we use a nominal bilateral exchange rate instead of an index. The nominal rate eliminates the need to convert the other variables, as argued by Khoo (1994). Besides, Mark (1990) shows that real and nominal changes are correlated for the seven countries used in his study, which is also supported by Atindehou and Gueyie (2001).

The most commonly currency used by Taiwanese companies is the American dollar therefore we employ the currency rate USD/TWD, meaning that if the domestic currency is appreciating, the change in the rate will be negative and the firm will benefit from it if the sign of the exposure coefficient is negative.

Our sample is made of 5245 observations, said 571,705 daily data.

As mentioned in the previous section, the difficulty in measuring magnitude asymmetries is to find an effective threshold which may depend on several factors such as the size of the firm or the industry to which the company belongs. The way to choose it is quite arbitrary. A rule of the thumb is to use as a starting point, the average exchange rate changes during the sample period.

Between 1990 and 2010, the average exchange rate change is $0.15 \%$. This low level is explained by the regular interventions of the CBC (Central Bank in Taiwan), especially at the end of the daily session. Even though the domestic currency (TWD) is appreciating, Taiwanese firms use to deal with a stable currency. Nevertheless, the average currency variation is increasing too: between 2009 and 2010 , it is about $0.22 \%$. Thus, it is logical to believe that Taiwanese firms will start to react if the change is greater than $0.22 \%$. Giving the fact that CBC uses to intervene on the foreign exchange market, we cannot expect a high daily change. We estimate that the threshold should be between $0.3 \%$ and $0.5 \%$ and decide to test the $0.5 \%$ level. As mentioned before, we are aware that it is an arbitrary choice.

\section{Empirical Results and Major Findings}

Table 1 provides the main results from our model (eq. 6).

Table 1. Main results

\begin{tabular}{|c|c|c|c|c|c|c|c|c|c|c|}
\hline & & & \multirow{2}{*}{\multicolumn{2}{|c|}{$\begin{array}{l}\text { Sample Size } \\
\text { Average Adj R² }\end{array}$}} & \multicolumn{6}{|l|}{107} \\
\hline & & & & & $35.31 \%$ & & & & & \\
\hline \multirow[t]{2}{*}{ Firms Exposed at } & $\beta 2$ & & $\beta 3$ & & $\beta 4$ & & $\beta 5$ & & $\gamma$ & \\
\hline & Qty & $\%$ & Qty & $\%$ & Qty & $\%$ & Qty & $\%$ & Qty & $\%$ \\
\hline $10 \%$ & 95 & $88.8 \%$ & 15 & $14.0 \%$ & 15 & $14.0 \%$ & 8 & $7.5 \%$ & 40 & $37.38 \%$ \\
\hline $5 \%$ & 90 & $84.1 \%$ & 8 & $7.5 \%$ & 11 & $10.3 \%$ & 4 & $3.7 \%$ & 35 & $32.71 \%$ \\
\hline $1 \%$ & 79 & $73.8 \%$ & 4 & $3.7 \%$ & 6 & $5.6 \%$ & 4 & $3.7 \%$ & 21 & $19.63 \%$ \\
\hline Details & $>0$ & $<0$ & $>0$ & $<0$ & $>0$ & $<0$ & $>0$ & $<0$ & $>0$ & $<0$ \\
\hline Firms Exposed(10\%) & 1 & 94 & 2 & 13 & 11 & 4 & 3 & 5 & 14 & 26 \\
\hline$\%$ of Exposed (10\%) & $1.05 \%$ & $98.95 \%$ & $13.3 \%$ & $86.7 \%$ & $73.3 \%$ & $26.7 \%$ & $37.5 \%$ & $62.5 \%$ & $35.00 \%$ & $65.00 \%$ \\
\hline Firms Exposed(5\%) & 0 & 90 & 0 & 8 & 7 & 4 & 0 & 4 & 12 & 23 \\
\hline$\%$ of Exposed (5\%) & $0 \%$ & $100 \%$ & $0 \%$ & $100 \%$ & $64 \%$ & $36 \%$ & $0 \%$ & $100 \%$ & $34 \%$ & $66 \%$ \\
\hline Firms Exposed(1\%) & 0 & 79 & 0 & 4 & 4 & 2 & 0 & 4 & 7 & 14 \\
\hline$\%$ of Exposed (1\%) & $0 \%$ & $100 \%$ & $0 \%$ & $100 \%$ & $67 \%$ & $33 \%$ & $0 \%$ & $100 \%$ & $33 \%$ & $67 \%$ \\
\hline Mean & 0.010563 & -0.02128 & 0.012347 & -0.0121 & 0.013525 & -0.01661 & & & & \\
\hline Median & & -0.01983 & 0.012347 & -0.01055 & 0.012872 & -0.01621 & & & & \\
\hline Standard Deviation & & 0.006789 & 0.001902 & 0.004575 & 0.003277 & 0.002812 & & & & \\
\hline Maximum & & -0.05217 & 0.013691 & -0.02583 & 0.018699 & -0.01985 & & & & \\
\hline Minimum & & -0.00876 & 0.011002 & -0.00725 & 0.009086 & -0.01418 & & & & \\
\hline
\end{tabular}

Notes: $\beta 2, \beta 3, \beta 4$ and $\beta 5$ measure respectively exchange rate exposure, sign asymmetry, magnitude asymmetry and currency volatility. $\gamma$ represents the volatility of stock returns underlying exchange rate exposure. 
Clearly, Taiwanese firms are exposed and we did not see similar percentages in the existing literature (at any level of acceptance). Moreover, Taiwanese companies (without exception, except 1 firm at the $10 \%$ level) see their value increasing when the TWD is appreciating.

Only $14 \%$ of the sample exhibit sign and/or magnitude asymmetries. Among companies having a sign asymmetry, the large majority shows a negative coefficient sign. It means that it not only increases the level of exposure, but it also works in favor of Taiwanese firms.

The magnitude asymmetry exhibits an opposite effect: for a large majority of the concerned firms, the coefficient is positive. This asymmetry reduces the level of exposure meaning that Taiwanese firms suffer from a large variation of the exchange rate.

The percentages of sign and magnitude asymmetries are too large to be ignored, but results show that the majority of Taiwanese firms is symmetrically exposed.

Concerning volatilities, only a small percentage of the sample exhibit significant exchange rate volatility impacts on stock returns: $7.5 \%$ at the $10 \%$ level of acceptance (3.7\% at the $1 \%$ and $5 \%$ levels). At the $10 \%$ level, for $37.5 \%$ of the concerned firms, the sign of the coefficient is positive, meaning that currency volatility has a positive impact on stock return. It does not match the conventional wisdom especially that our sample includes only non-financial firms. Normally from its effects on cash flows (as mentioned in section 2) exchange rate volatility should have a negative relationship with stock returns. But at the $1 \%$ and $5 \%$ levels of acceptance, all currency volatilities coefficients are negative which is conforms to the conventional wisdom (Note 10). Therefore at the $10 \%$ level, we may just have a statistical effect.

For a large part of our sample, we observe the existence of a volatility of stock returns underlying exchange rate exposure (the second volatility we investigated in this study): $37.38 \%$ ( $32.71 \%$ and $19.63 \%$ respectively at the $5 \%$ and $1 \%$ levels). Strangely, $3.7 \%$ of our sample (Note 11) exhibit it while not being exposed. We cannot ignore it, even though the asymmetric volatility is not an easy process to explain.

Besides, our study shows clearly that stock return volatilities are time dependant. All significant coefficients provide evidence (not reported here) that stock return volatilities are a function of its past value as well as past squared errors. Persistence, measured by $\beta_{\varepsilon, i}$ (in conditional variance of $\varepsilon_{i, t}$ ), is quite high with an average of 0.874. It suggests that there is a long memory in the stock return volatility process.

In this model, association to good news happens when $\varepsilon_{i, t}>0\left(\gamma_{i}=0\right)$ and bad news when $\varepsilon_{i, t}<0\left(\gamma_{i} \neq 0\right.$ is significant); If $\gamma_{i}$ is positive, bad news increases volatility (Note 12).

Our results show that only $35 \%$ of the volatility coefficients $\left(\gamma_{i}\right)$ are positive (thus increasing the volatility for the concerned firms). Usually, literature seems to mostly report positive coefficients, fact explained by the leverage effect or volatility feedback effect. So a large part of our Taiwanese sample facing volatility asymmetry exhibits a negative coefficient. The average positive coefficient $\gamma_{i}$ is 0.027 and -0.030 for the negative one $(+12.50 \%)$. It may seem counter-intuitive because it means that good news have a greater impact on the volatility than bad news, at least for $65 \%$ of the concerned firms. It shows that when good news hit the market, stock prices react positively and volatility increases all the more than if investors chase after good news, prices and volatility continue to rise. One explanation may be related to the trading noise hypothesis, investors having less useful trading information compared to investors in other stock markets and thus "chasing good news", see for example French and Roll (1986) who linked trading volume and return volatility.

We may say that chasing good news behavior is related to positive-feedback trading which is a price- or trend-chasing trading strategy. Shi et al. (2012) studying individual US stocks from 1980 to 2009 found that $9.4 \%$ of their sample exhibit positive-feedback activities. They also found that "these activities have a more profound effect on stocks with a higher level of information uncertainty".

Their findings may be another explanation of our results and support the "chasing good news behavior" hypothesis.

\section{Concluding Remarks}

Understanding exchange rate exposure and the various forms of volatilities is important in terms of firm valuation and risk management. If theory supports that firm value is impacted by currency changes, empirical evidences are mixed. We argue that sampling and methodology may be the reason for the weak evidences. In this study, we address the key issues mentioned in our introduction by choosing Taiwan which is a small and open economy. We also investigate asymmetries generated by the sign and amplitude of the exchange rate changes. 
Finally, we study the impacts of currency volatilities and volatilities of stock returns underlying exchange rate exposure.

Taiwan is clearly a good laboratory: we find that $88.8 \%, 84.1 \%$ and $73.8 \%$ (respectively at the $10 \%, 5 \%$ and $1 \%$ levels of acceptance) are exposed to exchange rate fluctuations. This high percentage has been seldom found in previous studies. Moreover, all Taiwanese firms are negatively exposed (except one at the $10 \%$ level) meaning that conversely to the theory, firms' value increase when the domestic currency is appreciating. Nevertheless, this result is supported by Moran (2005) who also investigated an open economy.

Only $14 \%$ of the sample exhibit a sign and/or magnitude asymmetries. Results show that Taiwanese firms benefit from the sign asymmetry (mostly having a negative coefficient sign) and suffer from the magnitude asymmetry (coefficients are mostly positive). If this percentage is too large to be ignored, it still shows that the majority of Taiwanese companies is symmetrically exposed.

Concerning volatilities, only a small percentage of the sample exhibit significant exchange rate volatility impacts on stock returns: $7.5 \%$ (3.7\% at the $1 \%$ and $5 \%$ levels). At the $1 \%$ and $5 \%$ levels of acceptance, all currency volatilities coefficients are negative which is conforms to the conventional wisdom and compatible with our results from the magnitude asymmetry.

For a large part of our sample, we also observe the existence of a volatility of stock returns underlying exchange rate exposure: $37.38 \%$ at the $10 \%$ level of acceptance $(32.71 \%$ and $19.63 \%$ respectively at the $5 \%$ and $1 \%$ levels). We also notice that there is a long memory in the stock return volatility process.

Our results show that $35 \%$ of the volatility coefficients are positive (thus increasing the volatility for the concerned firms). This sign is explained by the leverage effect or volatility feedback effect. So a large part of our Taiwanese sample facing volatility asymmetry exhibits a negative coefficient (while literature mostly report positive signs). It may seem counter-intuitive because it means that good news have a greater impact on the volatility than bad news, at least for $65 \%$ of the concerned firms.

It may be explained by a chasing good news behavior from the investors in the Taiwan stock market, hypothesis being supported by the trading noise assumption of French and Roll (1986) and the effects of a high level of information uncertainty according Shi et al. (2012).

\section{References}

Adler, M., \& Dumas, B. (1984). Exposure to Currency risk: Definition and Measurement. Financial Management, 13, summer, 41-50. http://dx.doi.org/10.2307/3665446

Allayannis, G. (1997). The time-variation of the exchange-rate exposure: An industry analysis. University of Virginia, Working Paper DSWP, 97-29.

Allayannis, G., \& Ihrig, J. (2001). Exposure and Markups. The Review of Financial Studies, 14(3), 805-835. http://dx.doi.org/10.1093/rfs/14.3.805

Allayannis, G., \& Ofek, E. (2001). Exchange Rate Exposure, Hedging and the Use of Foreign Currency Derivatives. Journal of International Money and Finance, 20, 273-296. http://dx.doi.org/10.1016/S0261-5606(00)00050-4

Amihud, Y. (1994). Evidence on Exchange Rates and Valuation of Equity Shares. In Y. Amihud \& R. M. Levich (Eds.), Exchange Rates and Corporate Performance (pp. 49-59). New York: Irwin Professional Publishing.

Andren, N. (2001). Is macroeconomic exposure asymmetric? Department of Business Administration, Lund University, Working Paper.

Atindehou, R. B., \& Gueyie, J. P. (2001). Canadian chartered banks' stock returns and exchange rate risk. Management Decision, 39, 285-295. http://dx.doi.org/10.1108/EUM0000000005463

Baldwin, R. (1988). Hysteresis in import prices: the Beachheld effect. American Economic Review, 78, 773-785.

Bartov, E., \& Bodnar, G. M. (1994). Firm Valuation, Earnings Expectations, and the Exchange-Rate Exposure Effect. Journal of Finance, 49(5), 1755-1785.

Bartram, S. M. (2004). Linear and Nonlinear foreign Exchange Rate exposure of German Non Financial Corporation. Journal of International Money and Finance, 23, 673-699.

Bartram, S. M., \& Bodnar, G. M. (2007). The exchange rate exposure puzzle. Managerial Finance, 33(9), 642-666. http://dx.doi.org/10.1108/03074350710776226

Bartram, S. M., \& Karolyi, G. A. (2006). The impact of the introduction of the Euro on foreign exchange rate 
risk exposures. Journal of Empirical Finance, 13(4-5), 519-49. http://dx.doi.org/10.1016/j.jempfin.2006.01.002

Bartram, S. M., Brown, G. W., \& Minton, B. A. (2010). Resolving the exposure puzzle: The many facets of exchange rate exposure. Journal of Financial Economics, 95, 148-173. http://dx.doi.org/10.1016/j.jfineco.2009.09.002

Bodnar, G. M., \& Gentry, W. M. (1993). Exchange Rate Exposure and Industry Characteristics: Evidence from Canada, Japan and the USA. Journal of International Money and Finance, 12, 29-45. http://dx.doi.org/10.1016/0261-5606(93)90008-Y

Bodnar, G. M., \& Marston, R. C. (2002). Exchange rate exposure: a simple model. In Choi, J. \& Power, M. (Eds.), International Finance Review, Vol. 3, Global Risk Management: Financial, Operational and Insurance Strategies (pp. 107-16). Elsevier Science, New York, NY, JAI, Greenwich, CT. http://dx.doi.org/10.1016/S1569-3767(02)03010-8

Bodnar, G. M., \& Wong, M. H. F. (2000). Estimating Exchange Rate Exposures: Some "Weighty" Issues. NBER Working Paper Series, Working Paper No. 7497.

Bodnar, G. M., \& Wong, M. H. F. (2003). Estimating exchange rate exposures: issues in model structure. Financial Management, 32(1), 35-67. http://dx.doi.org/10.2307/3666203

Bodnar, G. M., Dumas, B., \& Marston, R. C. (2002). Pass-Trough and Exposure. Journal of Finance, 57(1), 199-231. http://dx.doi.org/10.1111/1540-6261.00420

Brown, G. W. (2001). Managing Foreign Exchange Risk with Derivatives. Journal of Financial Economics, 60, 401-448. http://dx.doi.org/10.1016/S0304-405X(01)00049-6

Brunner, M., Glaum, M., \& Himmel, H. (2000). The DAX and the dollar: the economic exchange rate exposure of German corporations. Journal of International Business Studies, 31(4), 715-24.

Carter, D. A., Pantzalis, C., \& Simkins, B. J. (2005). Asymmetric exposure to foreign-exchange risk: financial and real option hedges implemented by U.S. multinational corporations. Oklahoma State University, Stillwater, Working Paper.

Chen, J., Naylor, M., \& Lu, X. (2004). Some Insights into the Foreign Exchange Pricing Puzzle: Evidence from a Small Open Economy. Pacific-Basin Finance Journal, 12, 41-64. http://dx.doi.org/10.1016/S0927-538X(03)00020-9

Choi, J., \& Prasad, A. M. (1995). Exchange Rate Sensitivity and its Determinants: A Firm and Industry Analysis of U.S. Multinationals. Financial Management, 24(3), 77-88.

Choi, J., Hiraki, T., \& Takesawa, N. (1998). Is foreign exchange risk priced in the Japanese stock market? Journal of Financial and Quantitative Analysis, 33, 361-382. http://dx.doi.org/10.2307/2331100

Chow, E. H., Lee, W. Y., \& Solt, M. E. (1997a). The Exchange-Rate Exposure of Asset Returns. Journal of Business, 70(1), 105-123.

Chow, E. H., Lee, W. Y., \& Solt, M. E. (1997b). The Economic Exposure of U.S. Multinational Firms. Journal of Financial Research, 20, 191-210.

Di Iorio, A., \& Faff, R. (2000). An analysis of asymmetry in foreign currency exposure of the Australian equities market. Journal of Multinational Financial Management, 10, 133-159. http://dx.doi.org/10.1016/S1042-444X(99)00024-9

Dixit, A. (1989). Entry and exit decisions under uncertainty. Journal of Political Economy, 97, 620-638.

Doidge, C., Griffin, J., \& Williamson, R. (2006). Measuring the economic importance of exchange rate exposure. Journal of Empirical Finance, 13, 550-76. http://dx.doi.org/10.1016/j.jempfin.2005.12.003

Dominguez, K. M. E., \& Tesar, L. L. (2001). A Re-Examination of Exchange Rate Exposure. NBER Working Paper Series, Working Paper No. 8128.

Dominguez, K., \& Tesar, L. (2006). Exchange rate exposure. Journal of International Economics, 68, 188-218. http://dx.doi.org/10.1016/j.jinteco.2005.01.002

Entorf, H., \& Jamin, G. (2003). German exchange rate exposure at DAX and aggregate level, international trade, and the role of exchange rate adjustment costs. ZEW (Centre for European Economic Research), Discussion Paper 03-04. 
Frazer, S. P., \& Pantzalis, C. (2004). Foreign Exchange Rate Exposure of US Multinational Corporations: A Firm-Specific Approach. Journal of Multinational Financial Management, 14(3), 261-281. http://dx.doi.org/10.1016/j.mulfin.2003.07.008

French, K. R., \& Roll, R. (1986). Stock Return Variance: the Arrival of Information and the Reaction of Traders. Journal of Financial Economics, 17, 5-26.

Friberg, R., \& Nydahl, S. (1999). Openness and the Exchange Rate Exposure of National Stock Markets. International Journal of finance and Economics, 4(1), 55-62. http://dx.doi.org/10.1002/(SICI)1099-1158(199901)4:1<55::AID-IJFE90>3.0.CO;2-1

Froot, K. A., \& Klemperer, P. D. (1989). Exchange rate pass-through when market share matters. Economic Review, 79, 637-654.

Giurda, F., \& Tzavalia, E. (2004). Is the currency risk priced in equity markets? Department of Economics, Queen Mary University of London, Working Paper 511.

Glaum, M., Brunner, M., \& Himmel, H. (1998). The DAX and the Dollar: the Economic Exchange-Rate Exposure of German Corporations. Europa-University Viadrina, Frankfurt, Germany, Working Paper.

Griffin, J., \& Stulz, R. (2001). International Competition and Exchange Rate Shocks: A Cross-Country Industry Analysis of Stock Returns. Review of Financial Studies, 14(1), 215-241. http://dx.doi.org/10.1093/rfs/14.1.215

He, J., \& Ng, L. K. (1998). The Foreign Exchange Exposure of Japanese Multinational Corporations. Journal of Finance, 53(2), 733-753. http://dx.doi.org/10.1111/0022-1082.295575

Heckman, C. (1985). A Financial model of foreign exchange exposure. Journal of International Business Studies, Summer, 83-99. http://dx.doi.org/10.1057/palgrave.jibs.8490452

Hsu, C. C, Yau, R., \& Wu, J. Y. (2009). Asymmetric exchange rate exposure and industry characteristics: evidence from Japanese data. Hitotsubashi Journal of Economics, 50, 57-69.

Hung, J. (1992). Assessing the Exchange Rate's Impact on U.S. Manufacturing Profits. Quarterly Review, Federal Reserve Bank of New York, Quarterly, 4, 44-63.

Hunter, D. M. (2005). Time-varying exchange rate exposure of small and large firms. College of Business Administration, University of South Florida, Working Paper.

Ihrig, J., \& Prior, D. (2005). The effect of exchange rate fluctuations on multinationals' returns. Journal of Multinational Financial Management, 15, 273-286. http://dx.doi.org/10.1016/j.mulfin.2004.09.004

Jorion, P. (1990). The Exchange-Rate Exposure of U.S. Multinationals. Journal of Business, 63(3), 331-345. http://dx.doi.org/10.1086/296510

Jorion, P. (1991). The Pricing of Exchange Rate Risk in the Stock Market. Journal of Financial and Quantitative Analysis, 26(3), 363-376. http://dx.doi.org/10.2307/2331212

Kanas, A. (2000). Volatility spillovers between stock returns and exchange rate changes. Journal of Business and Finance and Accounting, 27(3-4), 447-467. http://dx.doi.org/10.1111/1468-5957.00320

Khoo, A. (1994). Estimation of Foreign Exchange Exposure: an Application to Mining Companies in Australia. Journal of International Money and Finance, 13, 342-363. http://dx.doi.org/10.1016/0261-5606(94)90032-9

Kiymaz, H. (2003). Estimation of Foreign Exchange Exposure: An emerging Market Application. Journal of Multinational Management, 13, 71-84. http://dx.doi.org/10.1016/S1042-444X(02)00034-8

Knetter, M. M. (1994). Is export price adjustment asymmetric: evaluating market share and marketing bottlenecks hypotheses. Journal of International Money and Finance, 13, 55-70. http://dx.doi.org/10.1016/0261-5606(94)90024-8

Koutmos, G., \& Martin, A. D. (2003). Asymmetric Exchange Rate Exposure: Theory and Evidence. Journal of International Money and Finance, 22, 365-383. http://dx.doi.org/10.1016/S0261-5606(03)00012-3

Koutmos, G., \& Martin, A. D. (2007). Modeling time variation and asymmetry in foreign exchange exposure. Journal of Financial Management, 17, 61-74. http://dx.doi.org/10.1016/j.mulfin.2006.03.004

Kroner, K. F., \& Lastrapes, W. D. (1993). The Impact of Exchange Rate Volatility on International Trade: Reduced Form Estimates Using the GARCH-in-mean Model. Journal of International Money and Finance, 


\section{2, 298-318. http://dx.doi.org/10.1016/0261-5606(93)90016-5}

MAcRK, N. C. (1990). Real and nominal exchange rates in the long run: an empirical investigation. Journal of International Economics, 28, 115-136. http://dx.doi.org/10.1016/0022-1996(90)90052-N

Maghrebi, N., Holms, M. J., \& Pentecost, E. J. (2006). Are there asymmetries in the relationship between exchange rate fluctuations and stock market volatility in Pacific Basin Countries? Review of Pacific Basin Financial Markets and Policies, 9(2), 229-256. http://dx.doi.org/10.1142/S0219091506000719

Marston, R. (1990). Pricing to market in Japanese manufacturing. Journal of International Economics, 29 , 217-236. http://dx.doi.org/10.1016/0022-1996(90)90031-G

Meese, R. A., \& Singleton, K. J. (1982). On Unit Roots and the Empirical Modeling of Exchange Rates. Journal of Finance, 37, 1029-1035. http://dx.doi.org/10.2307/2327764

Miller, K. D., \& Reuer, J. J. (1998). Asymmetric Corporate Exposures to Foreign Exchange Rate Changes. Strategic Management Journal, 19(12), 1183-1191. http://dx.doi.org/10.1002/(SICI)1097-0266(1998120)19:12<1183::AID-SMJ1>3.3.CO;2-J

Moran, P. (2005). Foreign Exchange Exposure of Chilean Firms. Facultad de Ciencias Empresariales, Universidad de Talca, Chile, Working Paper.

Muller, A., \& Verschoor, W. F. C. (2006). Asymmetric foreign exchange risk exposure: evidence from U.S. multinational firms. Journal of Empirical Finance, 13, 495-518. http://dx.doi.org/10.1016/j.jempfin.2006.01.003

Muller, A., \& Verschoor, W. F. C. (2007). Asian foreign exchange risk exposure. Journal of the Japanese and International Economies, 21, 16-37. http://dx.doi.org/10.1016/j.jjie.2006.06.001

Nydahl, S. (1999). Exchange Rate Exposure, Foreign Involvement and Currency Hedging of Firms: Some $\begin{array}{llll}\text { Swedish Evidence. European Financial } & \text { Management, }\end{array}$ http://dx.doi.org/10.1111/1468-036X.00091

Patro, D., Wald, J., \& Wu, Y. (2002). Explaining Exchange Rate Risk in World Stock Markets: A Panel Approach. Journal of Banking and Finance, 1951-1972. http://dx.doi.org/10.1016/S0378-4266(01)00178-9

Priesley, R., \& Ødegaard, B. A. (2002). Linear and Non Linear Exchange Rate Exposure and the Price of Exchange Rate Risk. Norwegian School of Management, Working Paper No. 302409.

Priesley, R., \& Ødegaard, B. A. (2005). New evidence on exchange rate exposure. Norwegian School of Management, Working Paper.

Rosenberg, M. (2003). Exchange Rate Determination. McGraw Hill.

Rossi, Jr. J. L. (2008). Corporate foreign vulnerability, financial policies and the exchange rate regime: evidence from Brazil. Insper, IBMEC Sao Paulo, Working Paper.

ROSSI, Jr. J. L. (2009). Nonlinear foreign exchange exposure: evidence from Brazilian companies. Insper, IBMEC Sao Paulo, Working Paper 189/2009.

Sercu, P., \& Vanhule, C. (1992). Exchange Rate Volatility, International Trade and the Value of Exporting firms. Journal of Banking and Finance, 16, 155-182. http://dx.doi.org/10.1016/0378-4266(92)90083-C

Shi, J., Chiang, T. C., \& Liang, X. (2012). Positive-feedback trading activity and momentum profits. Managerial Finance, 38(5), 508-529. http://dx.doi.org/10.1108/03074351211217832

Tai, C. (2005). Asymmetric currency exposure of U.S. bank stock returns. Journal of Multinational Financial Management, 15, 455-472.

Williamson, R. (2001). Exchange Rate Exposure and Competition: Evidence from the Automotive Industry. Journal of financial Economics, 59, 441-475. http://dx.doi.org/10.1016/S0304-405X(00)00093-3

\section{Notes}

Note 1. See for example Jorion $(1990,1991)$ or Dominguez and Tesar (2006).

Note 2. See Friberg and Nydahl (1999); Total trade represents $140 \%$ of the GDP in 2008, compared to $24 \%$ in U.S.

Note 3. See Jorion (1990) and Bodnar and Wong (2000) for a discussion on the importance to include the market return.

Note 4. See more about orthogonalized models in section 3. 
Note 5. Bodnar and Gentry (1993) for example link it to the status of the market participants (exporter...).

Note 6. A company may be simultaneously an exporter and an importer.

Note 7. If $\beta_{2, i}$ is not significant, it may just mean that the firm has the same exposure behavior than the market.

Note 8. Finance theory stipulates that only unexpected changes in the exchange rate matters.

Note 9. We investigate firms' currency risk on the longest possible period of time and only 107 firms have available data for the sample period. We are aware of the potential survivorship bias in our conclusions.

Note 10. This is compatible with our results from the magnitude asymmetry (coefficients are mostly positive, thus affecting negatively the stock returns).

Note 11. Not reported here.

Note 12. It implies that in this case, bad news introduces more volatility than good news.

\section{Copyrights}

Copyright for this article is retained by the author(s), with first publication rights granted to the journal.

This is an open-access article distributed under the terms and conditions of the Creative Commons Attribution license (http://creativecommons.org/licenses/by/3.0/). 